\title{
Technology of the prospective social workers' training on pedagogical interaction in the process of studying professional disciplines
}

\author{
S. V. Mykhniuk, S. O. Kubitskyi \\ National University of Life and Environmental Sciences of Ukraine, Kyiv, Ukraine \\ Corresponding author. E-mail: serhiimykhniuk@nubip.edu.ua; kubitskiy@ukr.net \\ Paper received 18.12.20; Accepted for publication 02.01.21.
}

https://doi.org/10.31174/SEND-PP2021-245IX96-07

\begin{abstract}
The article outlines the technology of the prospective social workers' training on pedagogical interaction in the process of studying professional disciplines. The technology is a system of mutually agreed components (social, target, methodical, procedural, resulting), aimed at forming the readiness for pedagogical interaction in the prospective social workers through planning, organization and implementation of the process of studying the professional disciplines.

Keywords: the training of prospective social workers; the readiness of social workers for pedagogical interaction; training technology; professional disciplines, technologization.
\end{abstract}

Introduction. The social demand for projecting and implementation of the technology of the prospective social workers' training on pedagogical interaction is realized due to a number of factors:

- the need for scientifically grounded changes concerning the improving of the quality of prospective social workers' professional training;

- the need for the formation of universal and professional values, professionally significant personality qualities and patterns of behavior in the prospective professionals in the social sphere;

- the demand for socially transformative activities in the field of education (including non-formal education) as a tool for the development of civil society in Ukraine, and, accordingly, the demand for the professionals trained to implement pedagogical interaction.

Thus, the projecting technology of prospective social workers' training on pedagogical interaction in the process of studying professional disciplines is meant to meet the needs of the subjects in educational activities for achieving socially and professionally significant goals.

A brief overview of publications on the topic. The technology of the prospective social workers' training on pedagogical interaction in the process of studying professional disciplines is defined by us as a system of mutually agreed components (social, target, methodical, procedural, resulting) aimed at forming the readiness for pedagogical interaction in the prospective social workers through planning, organization and implementation of the process of studying the professional disciplines. This definition is consistent with the approaches to the technologicalization of pedagogical processes, outlined in the papers of $\mathrm{T}$. Grishina [2], I. Dychkivska [3], O. Naboka [6], N. Navolokova [7], O. Pekhota [8], I. Smolyuk [10], O. Yankovich [11]. The technology also corresponds to the procedural-descriptive dimension of the formulation of a concept (according to I. F. Prokopenko [9]). At the same time, the projecting of the author's technology of the prospective social workers' training on pedagogical interaction in the process of studying professional disciplines is determined by the need to improve the quality of professional education by saturating the content of professional training with modern technologies.

The purpose of the article: to design the technology of the prospective social workers' training on pedagogical interaction in the process of studying professional disci- plines; to characterize the essence of social, target, methodical, procedural, resulting components of the technology.

Materials and methods. In the process of our research we have used a set of research methods: the theoretical analysis for studying scientific sources on the problem of structuring the readiness of the prospective social workers for pedagogical interaction; the comparison method for comparing the scientific positions of different authors; the synthesis method for designing the technology of the prospective social workers' training on pedagogical interaction in the process of studying professional disciplines; the interpretation method for explaining and substantiating the author's position in the context of the problem under research.

Results and their discussion. The technology of the prospective social workers' training on pedagogical interaction in the process of studying professional disciplines is a professionally oriented studying technology, since it reflects both the logic of studying organization and a set of actions, forms and methods that ensure its impact on professionally significant results. Thus, the technologization of the process of prospective social workers' training on pedagogical interaction involves goal-setting and appropriate designing the content, forms, methods, stages of studying the professional disciplines, as well as diagnostics of the effectiveness of their impact on the studied quality - the level of readiness.

The structure of the technology of the prospective social workers' training on pedagogical interaction in the process of studying professional disciplines is determined by such components of the educational process: socially conditioned and motivational-value (social and target components of the technology), content (methodical component of the technology), procedural and personalityoriented (the procedural component of the technology), evaluative (resulting component of the technology).

The chosen structure enables providing the realizing of such characteristics of professionally oriented technologies of the training process, according to V. Korovin [5]:

- presence of some pedagogical and conceptual ideas social component;

- consistency of goals and actions, operations, communications, expected results - target component;

- purposefulness of the instructors and students methodological component; 
- possibility of replication and realization of the technology - procedural component;

- diagnostic procedures for determining the results of the application of the technology - effective component.

Let us describe major components of the technology and the methods of their implementation at the formative stage of our experiment.

The social component of the technology of the prospective social workers' training on pedagogical interaction in the process of studying professional disciplines determines the social demand, conceptual and theoretical principles of designing and implementation of the technology, as well as the principles of such implementation to meet the needs of professional training and the expectations of the technology.

In I. F. Prokopenko's paper [9] the leading characteristic of any technology includes a conceptual idea that determines the content and activities of all subjects in the technological process.

The conceptual idea of designing and implementing our technology is the need for interdisciplinary integration of social and psychological-pedagogical training of the prospective social professionals to ensure their ability to perform educational (including non-formal and civic education), upbringing, developmental, socializing functions of social transforming activities. The readiness of the prospective social workers for pedagogical interaction is provided by making changes in the content and methods of teaching the professional disciplines, taking into account all components of readiness for pedagogical interaction, the availability of methodological tools for assessing the readiness and appropriate program of its formation. The conceptual idea reflects such scientific approaches to the organization of the training on pedagogical interaction as system, competence, contextual, activity ones. It is the selected scientific approaches that reflect the basic principles of technologicalization of students' professional training on pedagogical interaction, thus determining the chosen forms, methods and content of transformational activities; the approaches also characterize the stages and directions of technology implementation in the process of studying the professional disciplines.

The principles of introduction of technology of the prospective social workers' training on pedagogical interaction in the process of studying professional disciplines correspond to the principles of designing and realization of professionally oriented technologies of professional training (according to O. Naboka [6]):

- the principle of conformity of teaching, learning and content of professional training;

- the principle of unity of educational, upbringing and developmental functions of education;

- the principle of connection of students' interests, motives and educational results;

- the principle of problem-solving educational tasks;

- the principle of combining individual and group forms of study;

- the principle of combining abstract, theoretical, visual, practical aspects of educational process;

- the principle of focusing on the activity and development of students;
- the principle of continuity of acquisition of professionally significant knowledge, skills, competencies.

It is the social component of the technology being reflected in the target component in the form of social demands, needs and expectations of the subjects in the process of technologicalization, as well as the initial conceptual and theoretical foundations of our research, that determine the strategic goal of technology design and implementation.

The target component of the technology of the prospective social workers' training on pedagogical interaction in the process of studying professional disciplines has a system-forming function and outlines the general purpose and tasks of the prospective social workers' training on pedagogical interaction.

Some researchers (I. F. Prokopenko [9]) consider the presence of the purpose and the corresponding priority of educational tasks, consistent with the expected results and conditions of technology's realization, to be an important factor in the effectiveness of pedagogical technologies. In general, as we have said, the goal in our technology is a system-forming element that determines the essence and content of the proposed pedagogical transformations.

The main purpose of the technology presupposes increasing the level of readiness in the prospective social workers for pedagogical interaction in the process of studying professional disciplines. Taking into account the scientific approaches and theoretical bases of formation of readiness in the prospective specialists for performance of certain professional functions, we are to realize the technology though several tasks:

- organization of educational activities in the process of studying professional disciplines, aimed at mastering professional knowledge, skills, competencies, including pedagogical interaction in the professional activity of social workers; this kind of activity presupposes such training forms, as lectures, practical and laboratory classes, consultations;

- development of quasi-professional activity aimed at reproducing models of pedagogical interaction in the process of teaching and studying professional disciplines;

- model in the subject and social content of pedagogical interaction; this kind of activity presupposes such training forms, as purposeful pedagogical interaction, game modeling;

- modeling of educational and professional activity in the process of studying professional disciplines taking into account the potential of pedagogical interaction as a tool for realization of professional functions of social workers; this kind of activity presupposes such training forms, as case study, project method, practice, scientific and research student work, volunteering;

- providing an informal educational component for the acquisition of professional and social skills, professionally significant personal qualities, competencies in the field of pedagogical interaction with clients of social work by the prospective social workers; this kind of activity presupposes such training forms, as trainings, special courses, professional workshops, educational and extracurricular work, volunteering).

According to A. Verbytsky's theory of contextual learning [1], the tasks of the technology are coordinated 
with the main types and forms of the prospective specialists' activity, during which training on pedagogical interaction is provided.

This method of formulating the tasks concerning the technologicalization process enables to systematically and purposefully cover the entire educational space of the professional training of the prospective social workers. The target component of the technology is reflected in the formulation of tactical and local goals of studying the professional disciplines, which is described in the methodical component.

The methodical component of the technology of the prospective social workers' training on pedagogical interaction in the process of studying professional disciplines presupposes the content, forms, and teaching methods, tested by us at the formative stage of the experiment to achieve the mentioned goal.

The content of professional training of the prospective specialists is characterized by the regularities of professional and pedagogical orientation of the educational process. This content determines the forms and methods of achieving the expected results of the introduced technology [9, p. 11].

The regularities of professional and pedagogical orientation of the process of studying the professional disciplines are determined by the following prerequisites:

- orientation on the connection between theory and practice, ensuring the duality of learning; development of professionalism of prospective specialists in social sphere, taking into account the individual trajectory of students' development;

- availability of educational environment, scientific and methodological space, favorable for comprehensive training of prospective specialists in social sphere, which presupposes taking into account the whole structure of readiness for pedagogical interaction (motivational, cognitive-content, operational-activity, reflexive-evaluation components);

- personality and socially oriented nature of technologicalization of the process of studying professional disciplines with taking into account modern social conditions and demands;

- filling the process of studying the professional disciplines with personality significance for the students with taking into account universal, democratic, humanistic values and social experience.

The content of the prospective social workers' training on pedagogical interaction in the process of studying professional disciplines consists of such elements as: knowledge about pedagogical interaction; the methods and techniques of its implementation in the professional activity of a social worker; the skills and abilities enabling to interact constructively with the clients of social work in the process of performing professional functions; the system of professional values; targets, emotional and conscious attitude to professional growth; the interest in professional development and self-realization.

Nowadays, the higher education institutions have autonomy concerning the formation of curricula and the choice of educational content. Accordingly, the institutions with the experimental research base have different educational programs and curricula for training the social workers. This situation affected the process of testing the technology. To implement the formative stage of the experiment, we have analyzed the curricula for the prospective social workers' training and identified professional disciplines aimed at forming similar program results. In particular, these are the professional disciplines, which have been studied by the prospective social workers' training on pedagogical interaction during the implementation of the technology:

- Training and organization of volunteers;

- Social and communication technologies;

- Fundamentals of public relations in social work;

- Social work in penitentiary institutions;

- Social counseling;

- Social work in the education system, etc.

The connection of professional disciplines with the goals and content of the technology of the prospective social workers' training on pedagogical interaction is given in table1.

To demonstrate the relationship between professional disciplines and the technology, we have chosen a strategic management approach, according to which the provision of long-term results is determined by the coherence of four types of goals: mission, strategic goal, tactical and operational goals [4].

The mission characterizes understanding the development of the educational process in its relationship with the external (social) conditions and internal characteristics of the stakeholders.

The strategic goal determines the direction of transformations and planned results of activity.

Tactical goals specify the expected results and take into account the actions required to achieve the strategic goal.

Operational goals reflect short-term specific tasks and methods of their realization.

The outlined hierarchy of the purposes of the technology enables to provide the system and purposefulness of transforming activity and to pick up effective tools for achieving the expected result.

The procedural component of the technology of the prospective social workers' training on pedagogical interaction in the process of studying professional disciplines characterizes the stages of the technology's implementation.

The stages of the technology of the prospective social workers' training on pedagogical interaction in the process of studying professional disciplines correspond to the structure of readiness for pedagogical interaction as the expected result of the technology implementation and, accordingly, are characterized by coherence, consistency, cross-cutting nature, purposefulness. In the process of the research work we have grounded the actualization, theoretical, practical and effective stages of the prospective social workers' training.

The actualization stage is correlated with the motivational component of the readiness of the prospective social workers for pedagogical interaction and determines the activities aimed at motivating the students for using the pedagogical interaction to solve professionally oriented tasks. At the actualization stage of the technology implementation, it is expedient to apply motivational and stimulating teaching methods, which include problem 
conversations, intellectual games, case studies, creative tasks, discussions.

Table 1. Ensuring the goals of the technology of the prospective social workers' training on pedagogical interaction in the process of studying professional disciplines

\begin{tabular}{|c|c|c|c|c|}
\hline Mission & \multicolumn{4}{|c|}{$\begin{array}{l}\text { Training of a motivated and competent specialist who possesses the pedagogical tools of social work to solve profes- } \\
\text { sional problems and to perform professional functions on the basis of universal and professional values }\end{array}$} \\
\hline $\begin{array}{c}\text { Strategic } \\
\text { goal }\end{array}$ & \multicolumn{4}{|c|}{$\begin{array}{c}\text { Increasing the level of readiness of the prospective social workers' training on pedagogical interaction in the process } \\
\text { of studying professional disciplines }\end{array}$} \\
\hline $\begin{array}{l}\text { Professional } \\
\text { disciplines }\end{array}$ & $\begin{array}{l}\text { Social work in the educa- } \\
\text { tion system }\end{array}$ & $\begin{array}{l}\text { Social counseling. } \\
\text { Technologies of social } \\
\text { work }\end{array}$ & $\begin{array}{c}\text { Social and communication technol- } \\
\text { ogies. } \\
\begin{array}{c}\text { Fundamentals of public relations in } \\
\text { social work }\end{array}\end{array}$ & $\begin{array}{l}\text { Training and organization } \\
\text { of volunteers }\end{array}$ \\
\hline & Knowledge & Skills & Communication & $\begin{array}{c}\text { Autonomy and responsibil- } \\
\text { ity }\end{array}$ \\
\hline $\begin{array}{l}\text { Tactical } \\
\text { goals }\end{array}$ & $\begin{array}{l}\text { Formation of knowledge } \\
\text { about pedagogical inter- } \\
\text { action, its content and } \\
\text { features }\end{array}$ & $\begin{array}{l}\text { Development of skills to } \\
\text { apply techniques and } \\
\text { methods of pedagogical } \\
\text { interaction in profes- } \\
\text { sional activity }\end{array}$ & $\begin{array}{l}\text { Formation of the ability to organize } \\
\text { pedagogical interaction in the per- } \\
\text { formance of professional functions }\end{array}$ & $\begin{array}{c}\text { Designing an author's } \\
\text { pedagogical program for } \\
\text { training volunteers for the } \\
\text { social sphere depending on } \\
\text { the category of clients and } \\
\text { specialization of social } \\
\text { service }\end{array}$ \\
\hline $\begin{array}{l}\text { Operational } \\
\quad \text { goals }\end{array}$ & $\begin{array}{l}\text { Considering the role and } \\
\text { place of pedagogical } \\
\text { interaction in the profes- } \\
\text { sional activity of a social } \\
\text { worker }\end{array}$ & $\begin{array}{l}\text { Mastering the tech- } \\
\text { niques and methods of } \\
\text { pedagogical interaction }\end{array}$ & $\begin{array}{c}\text { Considering the connection between } \\
\text { the professional functions of a } \\
\text { social worker and pedagogical } \\
\text { technologies }\end{array}$ & $\begin{array}{c}\text { Acquiring the skills of } \\
\text { planning and realization of } \\
\text { pedagogical interaction } \\
\text { with taking into account } \\
\text { social demands }\end{array}$ \\
\hline $\begin{array}{l}\text { Subject } \\
\text { matter }\end{array}$ & $\begin{array}{c}\text { Pedagogical interaction in } \\
\text { the activities of a social } \\
\text { worker }\end{array}$ & $\begin{array}{c}\text { Techniques and meth- } \\
\text { ods of pedagogical } \\
\text { interaction }\end{array}$ & $\begin{array}{l}\text { Professional functions of a social } \\
\text { worker and pedagogical technolo- } \\
\text { gies of their implementation }\end{array}$ & $\begin{array}{l}\text { Training of volunteers of } \\
\text { specialized social service }\end{array}$ \\
\hline Methods & $\begin{array}{l}\text { Case studies, presenta- } \\
\text { tions }\end{array}$ & $\begin{array}{c}\text { Business games, micro- } \\
\text { teaching }\end{array}$ & Workshop of the future, discussions & $\begin{array}{l}\text { Project method, } \\
\text { the Peer-to-Peer program }\end{array}$ \\
\hline
\end{tabular}

The theoretical stage is combined with the cognitivecontent component of readiness and is aimed at students' acquisition of the knowledge about pedagogical interaction, the possibilities of its application, techniques and implementation methods. Herewith it is important to use the methods of forming new knowledge, such as: reviewing the scientific articles, preparing presentations, abstracts, research projects, video lectures; the analysis of the experience of social workers, preparing the essays concerning summarizing different knowledge, informing procedure.

The practical stage correlates with the operational and activity component of the readiness; its purpose is to create pertinent conditions for the students to gain experience in pedagogical interaction to solve social, educational and professional problems. In the implementation of the practical stage it is important to use such practical teaching methods, as business games, project activities, micro-teaching, the Peer-to-Peer program, volunteering.

The resulting stage refers to the reflexive and evaluative component of the readiness, it is aimed both at diagnosing the existing level of readiness of the prospective social workers' training on pedagogical interaction and at building an individual trajectory of their professional growth. At the resulting stage, it is advisable to use testing, surveys, self-assessment, psychodiagnostic methods, discussion, goal setting.

The resulting component of the technology of the prospective social workers' training on pedagogical interaction in the process of studying professional disciplines determines the theoretical and methodological principles of diagnostics of the level of the readiness (the compo- nents of readiness for pedagogical interaction and their connection with criteria and indicators of measuring the level of readiness) and also outlines the expected result of the technology's implementation.

Since the main requirement for the technologicalization of the educational processes is the presence of a clearly defined result and the universality of its reproduction, then the substantiation in the resulting component the criteria for evaluating the results of training the prospective social workers for pedagogical interaction enables to comply with the requirements of scientificity, variability, accessibility [9]. Accordingly, we have outlined the expected result as the process of increasing the level of readiness of the prospective social workers for pedagogical interaction. In order to measure and assess the level of achieving the expected result, we differentiated certain criteria of readiness of the prospective social workers for pedagogical interaction - personalmotivational, semantic-content, activity-communicative, evaluative-reflexive.

Conclusion. Thus, the designed technology of the prospective social workers' training on pedagogical interaction in the process of studying professional disciplines reflects the strategic direction of transformative activity at the formative stage of the pedagogical experiment and describes a set of tools for its practical implementation in the process of prospective social workers' professional training. The prospects for further research are connected with the experimental verification of the designed technology and the developing of educational and methodological means for its implementation. 


\section{ЛIТЕРАТУРА}

1. Вербицкий А. А. Компетентностный подход и теория контекстного обучения. Москва : ИЦ ПКПС, 2004. 84 с.

2. Гришина Т. В. Освітня технологія як об'єкт методичної роботи. Харків : Основа, 2003. 96 с.

3. Дичківська I. М. Інноваційні педагогічні технології : навч. посібник. Київ : Академвидав, 2004. 352 с.

4. Калініна Л. М. Стратегічне управління освітньою організацією : навч. посіб. Ніжин : НДУ імені Миколи Гоголя, 2013. $104 \mathrm{c}$.

5. Коровин В. М. Технология профессиональноориентированного обучения в высшем учебном заведении. Вестн. Воронеж. гос. ун-та. 2007. №1. С. 97-100.

6. Набока О. Професійно-орієнтовані технології навчання у підготовці майбутніх педагогів. Рідна школа. 2011. №4-5 (квітень-травень). С. 31-35.
7. Наволокова Н. П. Енциклопедія педагогічних технологій та інновацій. Харків : Вид. група «Основа», 2012. 176 с.

8. Освітні технології : навч.-метод. посібник / О. М. Пехота, А. 3. Кіктенко, О. М. Любарська та ін.; за заг. ред. О. М. Пехоти. Київ : А.С.К., 2001. 256 с.

9. Педагогічні технології в підготовці вчителів : навч. посібник / кол. авторів ; за ред. І. Ф. Прокопенка. 3-є вид., допов. і переробл. Харків : ХНПУ, 2018. 457 с.

10. Смолюк I. О. Розвиток педагогічних технологій у вищих закладах освіти України : автореф. дис. на здобуття наук. ступеня д-ра пед. наук : 13.00.01. Київ, 1999. 35 с.

11. Янкович О. І. Освітні технології в історії розвитку вищої педагогічної освіти України (1957-2008): монографія. Тернопіль : Підручники і посібники, 2008. 320 с.

1. Verbickij A. A. Competence-based approach and contextual learning theory. Moskva : IC PKPS, 2004. $84 \mathrm{~s}$.

2. Hryshyna T. V. Educational technology as an object of methodical work. Kharkiv: Osnova, 2003.96 s.

3. Dychkivska I. M. Innovative pedagogical technologies : navch. posibnyk. Kyiv : Akademvydav, 2004. $352 \mathrm{~s}$.

4. Kalinina L. M. Strategic management of an educational organization : navch. posib. Nizhyn : NDU imeni Mykoly Hoholia, 2013. $104 \mathrm{~s}$.

5. Korovin V. M. The technology of professional oriented education in a higher education institution. Vestn. Voronezh. gos. un-ta. 2007. №1. S. 97-100.

6. Naboka O. Professionally oriented learning technologies in the training of prospective teachers. Ridnashkola. 2011. №4-5 (kviten-traven). S. 31-35.

7. Navolokova N. P. Encyclopedia of pedagogical technologies

\section{REFERENCES}

and innovations. Kharkiv : Vyd. hrupa «Osnova», 2012. 176 s.

8. Educational technologies : navch.-metod. posibnyk / O. M. Piekhota, A. Z. Kiktenko, O. M. Liubarska ta in.; zazah. red. O. M. Piekhoty. Kyiv : A.S.K., 2001. 256 s.

9. Pedagogical technologies in teacher training : navch. posibnyk / kol. avtoriv ; za red. I. F. Prokopenka. 3-ye vyd., dopov. i pererobl. Kharkiv : KhNPU, 2018. $457 \mathrm{~s}$.

10. Smoliuk I. O. Development of pedagogical technologies in higher educational institutions of Ukraine : avtoref. dys. na zdobuttia nauk. stupenia d-ra ped. nauk : 13.00.01. Kyiv, $1999.35 \mathrm{~s}$.

11. Iankovych O. I. Educational technologies in the history of higher pedagogical education in Ukraine (1957-2008) : monohrafiia. Ternopil : Pidruchnyky i posibnyky, 2008. 320 s. 